Jurnal IImiah

AVICENNA

ISSN : $1978-0664$

EISSN: $2654-3249$

\title{
GAMBARAN KADAR HEMOGLOBIN PADA MAHASISWA DENGAN KEBIASAAN MENGKONSUMSI MI INSTAN DI POLTEKKES KEMENKES BENGKULU
}

\section{OVERVIEW OF HEMOGLOBINE LEVELS IN STUDENTS WITH THE HABIT OF CONSUMING INSTANT NURES IN THE POLTEKKES OF THE MINISTRY OF HEALTH, BENGKULU}

\author{
Oleh : \\ Putri Widelia Welkriana1, Heru Laksono¹, Afisran Suhadi Pratama1 \\ ${ }_{1}^{1}$ Prodi TLM, Poltekkes Kemenkes Bengkulu (Jalan Indragiri no.3 Padang Harapan Bengkulu) \\ Email : putriwidelia5@gmail.com
}

\begin{abstract}
Background: Changes in the lifestyle of today's society also affect consumption patterns with the rise of instant food because noodles can be processed easily, served practically. Instant noodles are the favorite food of all circles of society, especially for people who have very many and pile up activities like students so that they don't have time to make or buy healthy food. The purpose of this study was to determine the description of hemoglobin levels in students with the habit of consuming instant noodles based on the characteristics of the respondents (Gender, Drinking Tea, Smoking, and Sleeping at Night) in the Health Analyst Department of the Health Polytechnic of the Ministry of Health, Bengkulu, 2020.

Methods: This research uses descriptive research with univariate data analysis. The sample in this study were 33 people using the total population method. The examination was carried out using the spectrophotometer method.

Results: The results of this study indicate that the hemoglobin levels in students with the habit of consuming instant noodles based on the characteristics of the respondent (gender, drinking tea, smoking habits, sleeping habits at night), obtained hemoglobin levels based on gender, almost half of the female respondents had abnormal hemoglobin levels. , $3 \%$, while a small proportion of male respondents' hemoglobin levels were in the normal category (12.1\%). Based on their tea drinking habits, almost half of them had abnormal hemoglobin levels (15.1\%). While respondents who drank tea sometimes a small proportion had abnormal hemoglobin levels $(15.1 \%)$, based on smoking habits, it was found that a small proportion of respondents who smoked had normal hemoglobin levels $(9.1 \%)$ and almost half of respondents who did not smoke had normal levels. Hemoglobin is not normal to normal $(30.3 \%)$. Based on the nighttime sleep habits, a small proportion of male respondents who often sleep at night have normal hemoglobin levels $(25 \%)$. and a small proportion of female respondents have abnormal hemoglobin levels $(25 \%)$.

Conclusion: $69.7 \%$ of respondents have normal hemoglobin levels after consuming instant noodles.
\end{abstract}

Keywords: Hemoglobin, Instant Noodles

\section{ABSTRAK}

Latar Belakang : Perubahan gaya hidup masyarakat masa kini turut mempengaruhi pola konsumsi dengan maraknya makanan instan karena mi dapat diproses dengan mudah, disajikan dengan praktis. Mi instan adalah makanan favorit dari semua kalangan masyarakat terutama bagi orang yang memiliki kesibukan yang sangat banyak dan bertumpuk-tumpuk seperti mahasiswa sehingga mereka tidak sempat untuk membuat ataupun membeli makanan yang sehat. Tujuan penelitian ini adalah Untuk diketahuinya gambaran kadar hemoglobin pada mahasiswa dengan kebiasaan mengkonsumsi mi instan berdasarkan karakteristik responden (Jenis Kelamin, Minum Teh, Merokok, dan Tidur Malam) di Jurusan Analis Kesehatan Poltekkes Kemenkes Bengkulu Tahun 2020.

Metode : Penelitian ini menggunakan jenis penelitian deskriptif dengan analisis data univariat. Sampel pada penelitian ini sebanyak 33 orang dengan menggunakan metode total populasi. Pemeriksaan dilakukan dengan menggunakan metode spektrofotometer.

Hasil : Hasil penelitian ini menunjukan bahwa Kadar hemoglobin pada mahasiswa dengan kebiasaan mengkonsumsi mi instan berdasarkan karakteristik responden (jenis kelamin, minum teh, kebiasaan merokok, kebiasaan tidur 
malam),didapatkan Kadar Hemoglobin berdasarkan jenis kelamin hampir sebagian responden perempuan memiliki kadar hemoglobin tidak normal 30,3\%, sedangkan sebagian kecil kadar hemoglobin responden laki-laki dalam kategori normal $(12,1 \%)$, berdasarkan kebiasaan minum teh hampir sebagian memiliki kadar hemoglobin tidak normal yaitu $(15,1 \%)$. Sedangkan responden yang minum teh kadang-kadang sebagian kecil memiliki kadar hemoglobin tidak normal $(15,1 \%)$, berdasarkan kebiasaan merokok didapatkan sebagian kecil responden yang merokok memiliki kadar hemoglobin normal $(9,1 \%)$ dan hampir sebagian responden yang tidak merokok memiliki kadar hemoglobin tdiak normal normal $(30,3 \%)$, berdasarkan kebiasaan tidur malam sebagian kecil responden lakilaki yang sering tidur malam memiliki kadar hemoglobin normal $(25 \%)$. dan sebagian kecil responden perempuan memiliki kadar hemoglobin tidak normal (25\%).

Kesimpulan : 69,7\% dari responden memiliki kadar hemoglobin normal.

Kata Kunci : Hemoglobin, Mi Instan

\section{PENDAHULUAN}

Berdasarkan data yang dikeluarkan World Instan Noodle Association (WINA) pada 2015, konsumsi mi instan di Indonesia mencapai 13,2 miliar bungkus dalam satu tahun. Dengan asumsi jumlah penduduk yang mencapai 260 juta orang, maka setiap satu orang Indonesia rata- rata mengkonsumsi 51 bungkus pertahun. Dengan konsumsi 13,2 miliar bungkus setahun, Indonesia berada diurutan ke 2 di dunia setelah China (Jannah, 2019).

Mi instan adalah makanan favorit dari semua kalangan masyarakat terutama bagi orang yang memiliki kesibukan yang sangat banyak dan bertumpuk-tumpuk sehingga mereka tidak sempat untuk membuat ataupun membeli makanan yang sehat seperti mahasiswa. Akan tetapi, mi instan belum dapat dianggap sebagai makanan penuh (wholesome food) karena belum mencukupi kebutuhan gizi yang seimbang bagi tubuh. Mi yang terbuat dari terigu mengandung karbohidrat dalam jumlah besar, tetapi kandungan protein, vitamin, zat besi dan mineralnya hanya sedikit. Pemenuhan gizi mi instan dapat diperoleh jika ada penambahan sayuran dan sumber protein (Ningsih, 2017).

Perubahan gaya hidup masyarakat masa kini turut mempengaruhi pola konsumsi dengan maraknya makanan instan. Makanan instan atau siap saji kian digemari sebagai makanan pengganti nasi. Salah satunya adalah mi instan yang sekarang ini banyak beredar terutama di kalangan remaja sebagai makanan populer (Marlenywati, 2015). Pergeseran pola konsumsi ini dimungkinkan karena mi dapat diproses dengan mudah, disajikan dengan praktis dan dapat memenuhi selera sebagian besar masyarakat, baik orang dewasa maupun anakanak. Promosi mi dengan berbagai jenis produk, ukuran dan harga yang terjangkau diberbagai tempat membuat produk mi baru cepat dikenal oleh masyarakat (Ningsih, 2017).

Memilih makanan cepat saji seperti mie instan sebagai pilihan dalam mengatasi rasa lapar menjadi salah satu alternatif. selain harganya yang murah dan mudah di dapatkan, rasanya yang bervariasi juga menjadi daya tarik tersendiri bagi remaja dalam mengkonsumsinya. Kandungan karbohidrat dan lemak yang tinggi, namun rendah protein, serat, vitamin dan mineral. Tidak membuat remaja menggurangi kebiasaan dalam mengkonsumsi mie instan tersebut. Asupan yang seharusnya dipenuhi dengan mengkonsumsi makanan yang kaya akan asupan gizi, vitamin terutama zat besi seperti daging, ikan, buah dan sayuran-sayuran hijau yang dapat membantu proses pembentukan sel darah merah. Dan menghindari terjadinya kasus anemia akibat sel darah merah yang disebabkan asupan zat besi yang kurang.

Hemoglobin merupakan zat protein yang terdapat dalam sel darah merah yang memberi warna merah pada darah dan merupakan pengangkut oksigen utama dalam tubuh. Pembentukan hemoglobin memerlukan 
bahanbahan penting, yaitu besi (Fe), vitamin B12, dan asam folat, zat besi merupakan komponen utama pembentukan heme pada hemoglobin. Rendahnya asupan zat besi dalam makanan merupakan faktor utama yang dapat memicu terjadinya anemia defisiensi zat gizi. Zat besi terdapat pada makanan seperti daging, ikan dan unggas (heme iron) dan pada tumbuhan seperti sayur, buah dan biji-bijian (nonheme iron). Zat besi yang berasal dari heme lebih mudah diserap oleh tubuh dibandingkan non heme. Asupan zat besi yang tidak adekuat dapat menyebabkan simpanan zat besi dalam tubuh akan berkurang sehingga suplai zat besi di sumsum tulang untuk pembentukan hemoglobin menjadi tidak adekuat. Akibat yang ditimbulkan adalah jumlah eritrosit protoporfirin bebas meningkat, terjadilah produksi eritrosit mikrositik dan nilai hemoglobin turun (Mantika, 2014).

Kekurangan nutrisi dapat berupa rendahnya asupan zat besi yang dapat menyebabkan terjadinya anemia defisiensi besi. Anemia merupakan suatu keadaan dimana kadar hemoglobin $(\mathrm{Hb})$ dalam darah dibawah normal yang diakibatkan oleh defisiensi salah satu atau beberapa zat gizi yang dibutuhkan dalam pembentukan sel darah merah. Kekurangan Hemoglobin dapat menyebabkan terjadinya anemia defisiensi besi adalah asupan protein yang rendah (Widyaji, 2017).

Berdasarkan observasi awal, mahasiswa Jurusan Analis Kesehatan tingkat 3 yang mengkonsumsi mi instan sebanyak 70 orang $(80,46 \%)$. Hal tersebut diperkuat dengan keseharian mahasiswa Analis Kesehatan memiliki kesibukan akademis yang sangat padat, baik dari segi kuliah maupun kegiatan kemahasiswaaan. Kesibukan yang alami oleh Mahasiswa Jurusan Analis Kesehatan tersebut menyebabkan mahasiswa harus membagi waktunya antara kebutuhan pribadi dengan kebutuhan akademik.

Kebiasaan yang sering terjadi pada mahasiswa adalah menunda waktu makan. Seringkali mereka hanya makan ketika makan siang dan makan malam saja, sedangkan makan pagi tidak dilakukan karena keterbatasan waktu, sehingga mereka tidak sempat untuk membuat ataupun membeli makanan yang sehat (Ningsih, 2017).

Konsumsi mi instan di kalangan mahasiswa khususnya remaja dan dewasa awal berpengaruh kepada status gizi dan peningkatan risiko menurunnya kadar hemoglobin yang akan menyebabkan anemia. Pengetahuan yang buruk dan minimnya uang saku mahasiswa akan dapat meningkatkan perilaku konsumsi mi instan. Berdasarkan latar belakang tersebut menjadikan peneliti tertarik melakukan penelitian mengenai gambaran kadar hemoglobin pada mahasiswa dengan kebiasaan mengkonsumsi mi instan di Jurusan Analis Kesehatan Poltekkes Kemenkes Bengkulu Tahun 2020.

\section{METODE}

Penelitian ini dilakukan pada bulan November 2019-April 2020 di Jurusan Analis Kesehatan Poltekkes Kemenkes Bengkulu dengan jenis penelitian deskriptif. Populasi dalam penelitian ini adalah seluruh Mahasiswa tingkat 3 Prodi DIII Teknologi Laboratorium Medis Tahun 2020 yang mengkonsumsi mi instan dan tinggal di kost. Sampel yang diambil pada penelitian ini adalah seluruh anggota populasi berjumlah 33 orang Total Populasi. Pemeriksaan sampel darah dilakukan di Laboratorium Analis Kesehatan Poltekkes Kemenkes Bengkulu untuk dilihat kadar Hemoglobin dari sampel penelitian.

\section{HASIL DAN PEMBAHASAN}

Analisis unuvariat digunakan untuk melihat distribusi frekuensi kadar hemoglobin pada mahasiswa dengan kebiasaan mengkonsumsi mi instan di Jurusan Analis Kesehatan Poltekkes Kemenkes Bengkulu Tahun 2020 berdasarkan Karakteristik responden (Jenis Kelamin, Minum Teh, Merokok, dan Tidur Malam) dengan jumlah 33 sampel. Hasilnya dapat dilihat pada tabel berikut : 
Tabel 1 Distribusi frekuensi kadar hemoglobin pada mahasiswa dengan kebiasaan mengkonsumsi mi instan berdasarkan Karakteristik responden (Jenis Kelamin, Minum Teh, Merokok, dan Tidur Malam) di Jurusan Analis Kesehatan Poltekkes Kemenkes Bengkulu

Kadar $\mathrm{Hb}$ Mahasiswa Dengan

Kebiasaan Mengkonsumsi Mi Instan Berdasarkan

Freku

Persenta Karakteristik Responden

\begin{tabular}{|c|c|c|c|c|}
\hline \multirow{6}{*}{$\begin{array}{c}\text { Jenis } \\
\text { Kelami } \\
n\end{array}$} & \multirow[t]{3}{*}{ Laki- Laki } & Normal & 4 & $12,1 \%$ \\
\hline & & Tidak & 0 & 0 \\
\hline & & Normal & & \\
\hline & \multirow{3}{*}{$\begin{array}{l}\text { Perempu } \\
\text { an }\end{array}$} & Normal & 19 & $57,6 \%$ \\
\hline & & Tidak & 10 & $30,3 \%$ \\
\hline & & Normal & & \\
\hline \multirow{6}{*}{$\begin{array}{l}\text { Minum } \\
\text { Teh }\end{array}$} & \multirow[t]{3}{*}{ Tiap Hari } & Normal & 10 & $30,3 \%$ \\
\hline & & Tidak & 5 & $15,1 \%$ \\
\hline & & Normal & & \\
\hline & \multirow{3}{*}{$\begin{array}{l}\text { Kadang- } \\
\text { kadang }\end{array}$} & Normal & 13 & $39,4 \%$ \\
\hline & & Tidak & 5 & $15,1 \%$ \\
\hline & & Normal & & \\
\hline \multirow{6}{*}{$\begin{array}{c}\text { Meroko } \\
\mathrm{k}\end{array}$} & \multirow{6}{*}{$\begin{array}{l}\text { Merokok } \\
\text { Tidak } \\
\text { Merokok }\end{array}$} & Normal & 3 & $9,1 \%$ \\
\hline & & Tidak & 0 & 0 \\
\hline & & Normal & & \\
\hline & & Normal & 20 & $60,6 \%$ \\
\hline & & Tidak & 10 & $30,3 \%$ \\
\hline & & Normal & & \\
\hline \multirow{6}{*}{$\begin{array}{l}\text { Tidur } \\
\text { Malam }\end{array}$} & \multirow{3}{*}{$\begin{array}{l}\text { Tidur } \\
\text { malam }\end{array}$} & Normal & 12 & $36,4 \%$ \\
\hline & & Tidak & 4 & $12,1 \%$ \\
\hline & & Normal & & \\
\hline & \multirow{3}{*}{$\begin{array}{l}\text { Tidak } \\
\text { tidur } \\
\text { malam } \\
\end{array}$} & Normal & 11 & $33,3 \%$ \\
\hline & & Tidak & 6 & $18,2 \%$ \\
\hline & & Normal & & \\
\hline
\end{tabular}

Pada Tabel 1 didapatkan Kadar Hemoglobin berdasarkan jenis kelamin hampir sebagian responden perempuan memiliki kadar hemoglobin tidak normal 30,3\%, sedangkan sebagian kecil kadar hemoglobin responden laki-laki dalam kategori normal (12,1\%), berdasarkan kebiasaan minum teh hampir sebagian memiliki kadar hemoglobin tidak normal yaitu $(15,1 \%)$. Sedangkan responden yang minum teh kadang-kadang sebagian kecil memiliki kadar hemoglobin tidak normal $(15,1 \%)$, berdasarkan kebiasaan merokok didapatkan sebagian kecil responden yang merokok memiliki kadar hemoglobin normal $(9,1 \%)$ dan hampir sebagian responden yang tidak merokok memiliki kadar hemoglobin tdiak normal normal $(30,3 \%)$, berdasarkan kebiasaan tidur malam sebagian kecil responden laki-laki yang sering tidur malam memiliki kadar hemoglobin normal (25\%). dan sebagian kecil responden perempuan memiliki kadar hemoglobin tidak normal $(25 \%)$.

Dari hasil penelitian kadar hemoglobin pada mahasiswa dengan kebiasaan mengkonsumsi mi instan di Jurusan Analis Kesehatan Poltekkes Kemenkes Bengkulu pada 33 orang mahasiswa didapatkan kadar hemoglobin normal sebanyak 23 orang $(69,7 \%)$. Dari 23 orang mahasiswa dengam kadar hemoglobin normal paling banyak didapatkan pada mahasiswa berjenis kelamin perempuan yaitu 19 orang. Menurut (Nugrahani, 2014) beberapa faktor yang mempengaruhi kadar hemoglobin seseorang diantaranya adalah jenis kelamin, yang mana pada perempuan sering dijumpai tidak normal dibandingkan laki-laki karena perempuan lebih mudah mengalami penurunan kadar hemoglobin dari pada laki-laki, terutama pada perempuan saat menstruasi yang disebabkan oleh keluarnya darah yang banyak yang terjadi selama beberapa hari dan mengalami penurunan kadar hemoglobin.

Namun pada penelitian ini didapatkan kadar hemoglobin normal pada mahasiswa yang berjenis kelamin perempuan, hal ini juga dikarenakan jumlah responden perempuan lebih banyak daripada responden laki-laki yaitu 29 orang $(87,9 \%)$, sedangkan responden laki-laki berjumlah 4 orang $(12,1 \%)$. Berdasarkan data yang didapatkan bahwa responden perempuan lebih pandai mengolah mi instan seperti sayur dan telur yang kaya akan vitamin dan protein yang baik untuk pembentukan hemoglobin.

Pada tabel 1 berdasarkan jenis kelamin kadar hemoglobin normal juga didapatkan pada responden laki-laki yang berjumlah 4 orang $(12,1 \%)$. Selain jenis kelamin, aktivitas fisik juga dapat mempengaruhi kadar hemoglobin 
seseorang, Aktivitas fisik yang dapat mempengaruhi kadar $\mathrm{Hb}$ ialah aktivitas fisik intensitas sedang hingga berat (Gunadi, 2016), hal ini juga didukung dari hasil pendataan responden laki-laki mempunyai kebiasaan melakukan olah raga seperti futsal dan jogging.

Saat melakukan aktivitas fisik seperti berolahraga akan terjadi peningkatan aktivitas metabolik yang tinggi, asam yang diproduksi berupa ion hidrogen dan asam laktat akan semakin banyak, hal ini akan menyebabkan terjadinya penurunan $\mathrm{pH}$. Afinitas antara oksigen dan hemoglobin akan menurun apabila $\mathrm{pH}$ darah rendah (Gibson, 2015). Apabila afinitas tarik antara oksigen dan hemoglobin menurun, maka hemoglobin akan melepaskan lebih banyak oksigen sehingga meningkatkan pengiriman oksigen ke otot (Gunadi, 2016).

Pada tabel 1 berdasarkan jenis kelamin didapatkan juga kadar hemoglobin tidak normal pada 10 mahasiswa perempuan. Salah satu faktor yang dapat menyebabkan tidak normalnya kadar hemoglobin pada perempuan yaitu masa menstruasi yang dialami perempuan setiap bulan (Sayojo, 2016), saat menstruasi yang disebabkan oleh keluarnya darah yang banyak yang terjadi selama beberapa hari dan mengalami penurunan kadar hemoglobin (Nugrahani, 2014).

Pada tabel 1 berdasarkan minum teh didapatkan kadar hemoglobin normal pada responden mengonsumsi teh berjumlah 23 orang $(69,7 \%)$, sedangkan kadar hemoglobin tidak normal pada responden yang mengkonsumsi teh didapatkan 10 orang $(30,3 \%)$. Kadar hemoglobin yang tidak normal pada pengonsumsi teh disebabkan oleh tanin pada teh dapat menghambat proses penyerapan zat besi yang bersumber dari non-heme sebesar $79-94 \%$ jika dikonsumsi bersamaan pada saat makan. Kandungan teh yang dapat memengaruhi penyerapan zat besi dari makanan disebut tanin. Penurunan absorpsi besi dapat menimbulkan anemia karena besi merupakan salah satu komponen yang membentuk struktur eritrosit. Pengaruh penghambatan tanin dapat dihindarkan dengan cara tidak minum teh pada saat makan dan setelah selesai makan agar tidak mengganggu penyerapan zat besi. Tanin yang terdapat dalam teh dapat menurunkan absorbsi zat besi sampai dengan $80 \%$. Minum teh satu jam sesudah makan dapat menurunkan absorbsi hingga $85 \%$. Batas aman untuk mengkonsumsi tanin dalam sehari adalah 750 $\mathrm{mg} / \mathrm{hari}$ atau setara dengan 5 cangkir teh berukuran $200 \mathrm{ml}$ (Lubis, 2016).

Pada Tabel 1 berdasarkan kebiasaan merokok didapatkan sebagian kecil kadar hemoglobin normal pada responden yang merokok (9,1\%). Dikarenakan Hemoglobin merupakan suatu protein tetrametrik dalam eritrosit yang berikatan dengan oksigen serta bertugas dalam melepaskan oksigen tersebut ke dalam jaringan. Selain itu, hemoglobin juga nantinya akan berikatan dengan karbon dioksida untuk mengembalikannya ke paru. Karbon monoksida yang terkandung dalam rokok memiliki afinitas yang besar terhadap hemoglobin, sehingga memudahkan keduanya untuk saling berikatan membentuk karboksihemoglobin, suatu bentuk inaktif dari hemoglobin. Hal ini mengakibatkan hemoglobin tidak dapat mengikat oksigen untuk dilepaskan ke berbagai jaringan sehingga menimbulkan terjadinya hipoksia jaringan. Tubuh manusia akan berusaha mengkompensasi penurunan kadar oksigen dengan cara meningkatkan kadar hemoglobin. Hal tersebut didukung juga walaupun responden merokok dan mengkonsumsi mi instan, tetapi responden tetap mengimbangi dengan makan makanan yang bergizi dan berolahraga yang teratur (Wibowo, 2017).

Dari 33 responden hanya 16 orang yang memiliki kebiasaan tidur malam. Pada Tabel 1 berdasarkan kebiasaan tidur malam didapatkan sebagian kecil kadar hemoglobin tidak normal pada responden yang memiliki kebiasaan tidur malam sebanyak 4 orang $(12,1 \%)$, sedangkan hemoglobin tidak normal pada responden yang tidak memiliki kebiasaan tidur malam sebanyak 6 orang $(18,2 \%)$. Menurut Sarjono (2016) tidur 
didefinisikan sebagai suatu keadaan bawah sadar saat orang tersebut dapat dibangunkan dengan pemberian ransangan yang juga merupakan proses yang sangat dibutuhkan manusia untuk pembentukan sel-sel tubuh yang baru, perbaikan sel-sel tubuh yang rusak maupun untuk menjaga keseimbangan metabolisme dan biokimiawi tubuh.

Kualitas tidur yang digambarkan dengan waktu tidur yang kurang akan membawa dampak bagi tubuh karena proses biologis yang terjadi saat tidur akan ikut terganggu. Salah satunya adalah pembentukan kadar hemoglobin yang terganggu dimana akan terjadi perubahan dimana kadar hemoglobin menjadi lebih rendah dari nilai normalnya. Hal ini karena pada saat tidur, didalam tubuh terjadi perbaikan sel-sel rusak, apabila durasi tidur kurang dari waktu yang ideal, hal ini akan meyebabkan proses pembaharuan sel-sel tersebut akan berjalan secara tidak maksimal dan akan mengganggu proses pembuatan hemoglobin sehingga jumlah hemoglobin yang diproduksi tidak akan mencukupi kebutuhan tubuh (Sarjono, 2016).

Berdasarkan lembar ceklis yang telah dilakukan selama penelitian dari 33 responden yang memiliki kebiasaan mengkonsumsi mi instan, didapatkan 7 orang responden mengkonsumsi mi instan tanpa menambahkan bahan tambahan yang dapat melengkapi kebutuhan gizi seperti sayur dan telur. Mi instan belum dapat dianggap sebagai makanan penuh karena belum dapat mencukupi gizi seimbang bagi tubuh. Pemenuhan kebutuhan gizi mi instan dapat diperoleh jika ada penambahan sayuran dan sumber protein (Ningsih, 2017).

Mahasiswa yang sering mengkonsumsi mi instan dapat dipengaruhi oleh pandangannya bahwa mengkonsumsi mi instan adalah hal yang biasa bagi anak kos-kosan serta mudah diolah. Mudahnya memperoleh mi instan juga dapat mempengaruhi responden untuk mengkonsumsi mi instan. Hal ini dapat dilihat dari ketersediaan fasilitas penjualan mi instan seperti pasar, supermarket, mini market, dan warung. Selain itu mi instan juga mempunyai rasa yang enak, mengenyangkan, tidak membosankan, berharga murah dan terjangkau. Berbagai kelebihan yang dimiliki menjadi pertimbangan bagi seseorang dalam memilih mi instan untuk dikonsumsi. Selain pandangan terhadap kelebihan mi instan, seseorang juga beranggapan bahwa mi instan perlu divariasikan dengan makanan lain. Hal ini berkaitan dengan pengetahuan seseorang tentang gizi yang baik, dimana responden mengetahui bahwa mi instan belum mengandung zat-zat gizi yang dapat memenuhi kebutuhan gizi tubuh. Berkaitan dengan jumlah mi instan, responden tidak menyajikannya secara berlebihan dalam setiap kali makan dan juga memvariasikan nya dengan makanan lain. Sebagian besar responden menyajikan 1 bungkus mi instan dalam setiap kali makan (Marlenywati, 2015).

\section{KESIMPULAN}

Kadar Hemoglobin berdasarkan jenis kelamin hampir sebagian responden perempuan memiliki kadar hemoglobin tidak normal 30,3\%, sedangkan sebagian kecil kadar hemoglobin responden laki-laki dalam kategori normal $(12,1 \%)$, berdasarkan kebiasaan minum teh hampir sebagian memiliki kadar hemoglobin tidak normal yaitu (15,1\%). Sedangkan responden yang minum teh kadang-kadang sebagian kecil memiliki kadar hemoglobin tidak normal $(15,1 \%)$, berdasarkan kebiasaan merokok didapatkan sebagian kecil responden yang merokok memiliki kadar hemoglobin normal $(9,1 \%)$ dan hampir sebagian responden yang tidak merokok memiliki kadar hemoglobin tdiak normal normal $(30,3 \%)$, berdasarkan kebiasaan tidur malam sebagian kecil responden laki-laki yang sering tidur malam memiliki kadar hemoglobin normal (25\%). dan sebagian kecil responden perempuan memiliki kadar hemoglobin tidak normal $(25 \%)$. 
Penelitian ini mempunyai saran antara lain bagi akademik yaitu hendaknya dapat mensosialisasikan kepada mahasiswa dalam mengkonsumsi mi instan agar nilai gizinya bermanfaat bagi tubuh sehingga bias mencegah terjadinya anemia defisiensi besi. Bagi masyarakat yaitu supaya mengadakan perbaikan gizi terutama tingkat asupan zat besi dan agar menghindari mengkonsumsi mi instan secara berlebihan karena zat besi yang terkandung dalam mi instan sangatlah sedikit. Bagi peneliti selanjutnya yaitu agar menganalisis atau mencari hubungan dan faktor-faktor yang dapat mempengaruhi peningkatan dan penurunan kadar hemoglobin seperti penyakit sistemik, aktivitas fisik, usia, kecukupan besi dalam tubuh, dan pola makan. Penelitiannya dapat dilakukan dengan memperbanyak sampel yang diteliti, dan meggunakan metode pemeriksaan yang lebih efektif dan efisien sehingga didapatkan hasil yang lebih maksimal.

Gibson, J. 2015. Fisiologi dan Anotomi Modern Untuk Perawat. Jakarta: EGC.

Gunadi. (2016). Gambaran Kadar Hemoglobin Pada Pekerja Bangunan. 4, 2-7.

Jannah, S. \& F. (2019). Posisi Label Halal Dalam Keputusan Konsumen Pada Pembelian Mie Instan Di Segmen Remaja. 3(2016), 128133.

Lubis, T. M. (2016). Pengaruh Pemberian Ekstrak Teh Hijau (Camelia Sinensis) Terhadap Penurunan Kadar Hemoglobin Dan Nilai Hematokrit Pada Tikus Wistar (Rattus Norvegicus). 141-143.

Mantika, A. I. (2014). Hubungan Asupan Energi,
Protein, Zat Besi Dan Aktivitas Fisik Dengan Kadar Hemoglobin Tenaga Kerja Wanita Di Pabrik Pengolahan Rambut Pt. Won Jin Indonesia. 1-38.

Marlenywati, R. (2015). Perilaku Konsumsi Mie Instan Mahasiswa Fakultas IImu Kesehatan Universitas Muhammadiyah Dan Jurusan Gizi Poltekkes Kemenkes Pontianak. Jurnal Vokasi Kesehatan, Volume I Nomor 6 Nopember 2015, HIm. 188 - 194.

Ningsih. (2017). Hubungan Pengetahuan Dan Frekuensi Konsumsi Makanan Berisiko (Mie Instan) Dengan Kejadian Gastritis Di Kelurahan Kampung Baqa Wilayah Kerja Puskesmas Kampung Baqa Samarinda Seberang.

Nugrahani, I. (2014). Perbedaan Kadar Hemoglobin Sebelum Dan Sesudah Menstruasi Pada Mahasiswa Diii Keperawatan Universitas Muhamadiyah Surakarta.

Sarjono, L. (2016). Perbedaan Kadar Hemoglobin Pada Mahasiswa Fakultas Kedokteran Universitas Sam Ratulangi Berdasarkan Kualitas Tidur. 4, 5-8.

Sayogo, S. (2016). Gizi remaja putri. Jakarta: EGC.

Wibowo, D. V. (2017). Hubungan Merokok Dengan Kadar Hemoglobin Dan Trombosit Pada Perokok Dewasa. 5.

Widyaji. (2017). Hubungan Pengeluaran Rumah Tangga , Asupan Protein , Dan Asupan Zat Besi Dengan Kadar Hemoglobin Pada Pekerja Tambang Pasir Tradisional. 220226. 